\title{
URGENSI PERATURAN PEMERINTAH \\ TENTANG PERDAGANGAN ELEKTRONIK \\ DALAM KAITANNYA DENGAN PENERAPAN PAJAK \\ PADA TRANSAKSI E-COMMERCE
}

\author{
Nanin Koeswidi Astuti ${ }^{1}$
}

\begin{abstract}
E-commerce is a trade in goods and services via the Internet or other electronic means. Legally e-commerce transactions without knowing the geographic boundaries will cause a lot of problems in practice in the field on the issue of taxation of income from e-commerce transactions conducted. Whether existing tax provisions currently supports e-commerce transactions and whether the urgency of government regulations on electronic commerce to taxation on e-commerce transactions. This study is a literature review with descriptive design. The results showed that the existing tax provisions not support e-commerce transactions themselves. Regarding the determination of an e-commerce transaction is considered to have a permanent establishment (BUT) in relation to the subject of taxes, UU RI No. 36 year 2008 Article 5, paragraph (1) letter p on permanent establishment, but this provision is not complete because it has not explained in specific about the types of ecommerce transactions as recommended in the OECD TAG that there are 28 types of transactions that most of the e-commerce transactions generate revenues and royalties. Seeing the enormous potential state revenues from the sector income tax taxpayers in e-commerce transactions that, then the urgency of government regulations on electronic commerce to taxation on e-commerce transactions should be enacted so happens legal certainty in e-commerce transactions and government as authorities levy taxes. But before electronic trading RPP passed into government regulation, should DJP need more in-depth assessment of the contents of $R P P$ with related parties transactions involving e-commerce.
\end{abstract}

\section{Kata Kunci: Penerapan Pajak Elektronik dan Transaksi E-Commerce}

\section{PENDAHULUAN}

Kemajuan teknologi informasi (TI) yang pesat memberikan kemudahan dalam hubungan antar negara, dimana batas geografis seolah dalam kondisi tanpa batas (borderless). Perkembangan tehnologi informasi sering disebut internet, memberikan kontribusi yang cukup besar bagi masyarakat, pemerintah, maupun dunia industri atau perusahaan. Dalam kegiatan perdagangan berbasis internet yang dikenal dengan nama e-commerce.Perkembangan e-commerceseiiring dengan laju perkembangan internet. Pertumbuhan pengguna Internet di Indonesia pada tahun 2014 tercatat sebanyak 88,1 juta, tumbuh 16,2 juta dari sebelumnya 71,9 juta atau dengan kata lain memiliki penetrasi $34,9 \%^{2}$ disesuaikan dengan jum-

\footnotetext{
${ }^{1}$ Dosen Tetap Fakultas Hukum UKI.

${ }^{2}$ Semuel A. Pangerapan, "Pengguna Internet Indonesia Tembus 88,1 juta", Asosiasi Penyelenggara Jasa Internet Indonesia (AP- JII), http://inet.detik.com/read//pengguna-internet-indonesia-tem- bus881-juta, diunduh pada tgl. 28 Juni 2015, jam. 12.00.
}

lah penduduk di Indonesia yang mana pada tahun 2014. Badan Pusat Statistik mendata sedikitnya jumlah penduduk di Indonesia mencapai 252 juta. Hal inilah yang menyebabkan e-commerce mulai tumbuh dan berkembang dengan pesat dalam beberapa tahun terakhir di Indonesia.

Penggunaan internet dalam dunia perdagangan sebagai salah satu media pemasaran yang efektif dan efisien baik bagi perusahaan maupun masyarakat dalam mengiklankan produk barang dan jasa ke calon customer ke seluruh dunia. Dalam e-commercekecepatan akses informasi, kenyamanan, flexibilitas, kemudahan dan rendahnya cost menyebabkan banyak pengusaha konvensional beralih menggunakan media internet untuk berdagang.

Kementrian Perdagangan (Kemendag) baru-baru ini melakukan uji publik Rancangan Peraturan Pemerintah (RPP) tentang Perdagangan Secara Elektronik (e-commerce) dengan mengadakan diskusi dengan pelaku e-commerce dimana RPP tersebut telah me- 
lewati proses hukum selama 2 tahun. RPP tersebut merupakan aturan turunan dari Undang-Undang RI Nomor. 7 Tahun 2014 tentang Perdagangan Pasal 65 dan Pasal 66. Hal inilah yang menyebabkan hubungan antara pemerintah dan Asosiasi E-Commerce Indonesia (idEA) sempat memanas. Pelaku bisnis $e$ commerce mengaku kecewa dengan sikap Kemendag, dalam penyusunan RPP mengenai perdagangansecara elektronik. Kemendag dianggap tidak koooperatif dan transparans dalam penyusunan perangkat hukum tersebut. idEA mengungkapkan, selama dua tahun pembahasan RPP, kalangan asosiasi tidak sekalipun diberikan akses terhadap materi draft maupun status dari dokumen tersebut. Padahal pelaku bisnis e-commerce sudah melayangkan permintaan secara formal maupun informal. Salah satu hal yang dikhawatirkan pelaku E-Commerce adalah mengenai pajak dan kebijakan Know Your Customer (KYC). ${ }^{3}$

Pajak merupakan instrumen yang penting bagi negara dan masyarakat sebagai wajib pajak. Pajak sebagai salah satu penyumbang terbesar dari penerimaan negara bahkan diperkirakan mencapai $70 \%$, karena itulah pajak merupakan ujung tombak pembangunan sebuah negara.Pembayaran pajak merupakan perwujudan dari kewajiban kenegaraan dan peran serta Wajib Pajak untuk secara langsung dan bersama-sama melaksanakan kewajiban perpajakan untuk pembiayaan negara dan pembangunan nasional. ${ }^{4}$ Demikian pula halnya dengan kewajiban Wajib Pajak yang melakukan transasksi e-commerce selama berada di wilayah Indonesia untuk membayar pajak tanpa terkecuali.Secara hukum transaksi e-commerce yang tanpa mengenal batas geografis akan menimbulkan banyak sekali permasalahan dalam praktik di lapangan, diantaranya mengenai segala jenis pendapatan dari berbagai model bisnis e-commerce, masalah identitas pedagang,cara pemungutan pajak bagi wajib pajak orang asing (luar negeri) dimana server berada di luar negeri dan posisinya sulit dilacak. Sehingga sektor perpajakan harus mampu mengantisipasi dengan membuat kebijakan-kebijakan yang sesuai dengan perkembangan teknologi informasi, khususnya kebijakan mengenai pajak penghasilan mengenai transaksi e-commerce.

\footnotetext{
${ }^{3}$ Tedy Gumilar, dkk, "Industrinya Masih Baru, Ogah Dipajaki Dulu“, Tabloid Kontan, 29 Juni-5 Juli 2015, hal.4-5.

${ }^{4}$ Muhammad Iqbal, "Pajak Sebagai Ujung Tombak Pembangunan", http://www.pajak.go.id/content/article/pajak-sebagai-ujung-tombak-pembangunan, diunduh pada tgl. 28 Juni 2015, jam. 18.00.
}

\section{PERMASALAHAN}

1. Apakah ketentuan perpajakan yang ada saat ini telah mendukung transaksi e-commerce

2. Apakah urgensi Peraturan Pemerintah tentang perdagangan elektronik terhadap pengenaan pajak pada transaksi e-commerce

\section{TUJUAN PENULISAN}

1. Untuk mengetahui ketentuan perpajakan dalam mendukung transaksi e-commerce.

2. Untuk mengetahui pentingnya penerapan pajak pada setiap transaksi e-commerce yang dilakukan oleh pemerintah dalam upaya meningkatkan pendapatan negara dari sektor pajak.

\section{PENGERTIAN E-COMMERCE}

Menurut Departement of Economic and Social Affair yang dimaksud dengan e-commerce adalah:

"Production units receive orders and transact the sale of goods and services produced by a variety of means, such as by telephone, fax, television or over the Internet. Many countries have chosen to describe as e-commerce any business transaction that transfers the ownership of the goods or service through the Internet or by other electronic means". "There are three stages in the transfer of the ownership of a good or service: (a) the placement of the order, (b) the payment and (c) the delivery of the good or service.". 5

Definisi di atas dapat diartikan bahwa:

Unit produksi menerima pesanan dan bertransaksi menjual barang dan jasa yang dihasilkan dengan berbagai cara, seperti melalui telepon, fax, televisi atau melalui internet.Banyak negara sepakat menggambarkan e-commerce sebagai transaksi bisnis yang memindahkan kepemilikan barang atau jasa melalui internet atau dengan cara elektronik lainnya. Ada tiga tahapan dalam pemindahan kepemilikan dari barang atau jasa: (a) penempatan pesanan, (b) pembayaran dan (c) pengiriman barang atau jasa.

Menurut Onno W Purbo dan Aang Wahyudi yang mengutip pendapatnya David Baum:

"E-Commerce is a dynamic set of technologies, aplications, and business procces that link enterprises, consumers, and communities through elec-

\footnotetext{
${ }^{5}$ Departement of Economic and Social Affairs, "International Standard Industrial Classification of All Economic Activities". New York, 2008, Rev.IV. page. 28.
} 
tronic transaction and the electronic exchange of goods, services and information".

Definisi di atas dapat diartikan bahwa:

E-commerce merupakan suatu set dinamis teknologi, aplikasi, dan proses bisnis yang menghubungkan perusahaan, konsumen dan komunitas melalui transaksi elektronik dan perdagangan barang, pelayanan, dan informasi yang dilakukan secara elektronik. ${ }^{6}$

Menurut Kalakota dan Winston, definisi e-commerce dapat ditinjau dari beberapa perspektif:

1. Dari perspektif komunikasi, e-commerce ada- lah pengiriman barang, layanan, informasi, atau pembayaran melalui jaringan komputer atau melalui peralatan elektronik lainnya.

2. Dari perspektif proses bisnis, e-commerce adalah aplikasi dari teknologi yang menuju otomatisasi dari transaksi bisnis dan aliran kerja.

3. Dari perspektif layanan, e-commerce merupakan suatu alat yang memenuhi keinginan perusahaan, konsumen, dan manajemen untuk memangkas biaya layanan (service cost) ketika meningkatkan kualitas barang dan meningkatkan kecepatan layanan pengiriman.

4. Dari perspektif online, e-commerce menyediakan kemampuan untuk membeli dan menjual barang ataupun informasi melalui internet dan sarana online lainnya. ${ }^{7}$

UU RI No. 7 tahun 2014 tentang Perdagangan, mendefinisikan perdagangan melalui sistem elektronik adalah perdagangan yang transaksinya dilakukan melalui serangkaian perangkat dan prosedur elektronik. ${ }^{8}$

Dalam Rancangan Peraturan Pemerintah tentang Perdagangan Elektronik, definisi tentang perdagangan elektronik adalah:

"Perdagangan elektronik adalah pertukaran barang atau jasa melalui internet dan media elektronik lainnya, meliputi komunikasi, transaksi, dan penyelesaian mekanisme pembayaran sesuai dengan prinsip dasar yang berlaku pada perdagangan tradisional dimana pembeli dan penjual melakukan pertukaran barang dan jasa dengan media uang". ${ }^{9}$

\footnotetext{
${ }^{6}$ Onno W. Purbo dan Aang Arif Wahyudi, "Mengenal E-Commerce", Jakarta: Elek Media Komputindo, 2001, hal. 2.

${ }^{7}$ M. Suyanto, "Strategi Periklanan pada e-commerce Perusahaan Top Dunia“, Yogyakarta: Andi, 2003, hal.11.

${ }^{8}$ Pasal 1 (24) UU No. 7 tahun 2014 tentang Perdagangan.

9 http://id.scribd.com/doc/65509415/Naskah-Akademik-RPP-Perdagangan-Secara-Elektronik\#scribd, diunduh pada tgl. 28 Juni 2015, jam. 19.00.
}

Secara umum e-commerce merupakan suatu perdagangan barang dan jasa melalui media internet atau sarana elektronik lainnya.

\section{KETENTUAN HUKUM MENGENAI TRANSAKSI E-COMMERCE}

Dari segi hukum perdata, perjanjian jual beli adalah suatu perjanjian dimana pihak yang satu mengikatkan dirinya untuk menyerahkan suatu kebendaan, dan pihak yang lain untuk membayar harga yang dijanjikan. ${ }^{10}$ Perjanjian jual beli dalam transaksi e-commerce juga terikat dengan perjanjian jual beli yang diatur dalam KUHPerdata, walaupun berbeda cara dan juga media atau sarana dalam melakukan transaksi dagang.

Perjanjian jual beli dalam transaksi e-commerce juga menganut sistem terbuka sesuai dengan asas kebebasan berkontrak dalam Pasal 1338 ayat (1) KUHPerdata:

"Semua perjanjian yang dibuat secara sah berlaku sebagai undang-undang bagi mereka yang membuatnya". Kata semua, mengandung pengertian bahwa kita diperbolehkan membuat perjanjian dalam bentuk dan mengenai apa saja dan perjanjian yang dibuat akan mengikat para pihak yang membuatnya sebagai sebuah undang-undang. Perjanjian jual beli dalam e-commerce merupakan suatu bentuk perjanjian yang mengikuti perkembangan dunia perniagaan dalam masyarakat.

Asas konsensualisme dalam Pasal 1320 KUHPerdata juga berlaku dalam perjanjian jual beli dalam ecommerce, dimana perjanjian sudah dilahirkan pada detik tercapainya kesepakatan atau dengan kata lain perjanjian sudah sah apabila sudah sepakatmengenai hal-hal yang pokok dan formalitas tidak diperlukan dalam hal ini.

Peranan besar pemerintah dalam perekonomian tersirat dalam Pasal 33 ayat (2) dan (3) UUD 1945 ${ }^{11}$. Dalam fungsinya sebagai stabilitator pemerintah menciptakan kestabilan ekonomi, sosial, politik, hukum, serta pertahanan keamanan. Dalam bidang perdagangan mekanisme pasar tidak dapat berfungsi dengan baik jika tiada hukum yang dibuat oleh pe-

\footnotetext{
${ }^{10}$ Pasal 1457 KUHPerdata.

${ }^{11}$ Ayat (2): Cabang-cabang produksi yang 15 enting bagi negara dan yang menguasai hajat hidup orang banyak dikuasai oleh negara. Ayat (3): Sumber air, dan kekayaan alam yang terkandung di dalamnya dikuasai oleh negara, dan dipergunakan untuk sebesar-besarnya kemakmuran rakyat
} 
merintah, karena hukum memberikan landasan bagi penerapan peraturan dalam praktik termasuk juga pemberian sanksi bagi para pelaku yang melanggar peraturan dalam bidang perdagangan. Penegakan hukum hanya dapat ditegakkan dengan peraturan-peraturan yang dibuat oleh pemerintah.

Peranan pemerintah dalam penyelenggaraan teknologi informasi dan transaksi elektronik adalah selain sebagai penyedia fasilitas dalam tehnologi informasi dan transaksi elektronik juga melindungi kepentingan umum dari tindakan penyalahgunaan tehnologi informasi dan transaksi elektronik sesuai dengan peratu- ran perundang-undangan yang dibuatnya.Pengaturan transaksi e-commerce dalam UU RI No.11 tahun 2008 tentang Informasi dan Transaksi Elektronik, bisa dikatakan sebagai harmonisasi hukum konvensional ke hukum modern. e-commerce diatur dalam beberapa pasal, diantaranya Pasal 10, Pasal 17 ayat (3), Pasal 18 ayat (1) dan (3), Pasal 19, Pasal 21 dan Pasal 22. Dalam Pasal 17 ayat (3) dibutuhkan peraturan pemerintah dalam penyelenggaraan transaksi elektronik.

\section{TRANSAKSI PADA PERDAGANGAN ELEKTRONIS}

Perjanjian Perdagangan Elektronis adalah bentuk perjanjian jual beli yang memiliki kekuatan hukum yang sama dengan perjanjian konvensional, dimana bukti transaksi elektronik diakui ekuivalen dengan bukti dokumen yang ditulis (Pedoman UNCITRAL). Diperlukan ketentuan-ketentuan baru terkait perdagangan elektronik dalam koridor hukum positif di Indonesia dengan penekanan pada:

1. Hubungan sejajar antara pelaku usaha dan konsumen Memberikan ruang tawar lebih luas bagi konsumen dalam format kontrak baku.

2. Pemberlakuan sistem " 3 klik" dalam kesepakatan kontrak transaksi perdagangan elektronik.

3. Pengakuan tanda tangan elektronis dan data message.

4. Akseptabilitas penggunaan media online lain sebagai alat pembuktian kesepakatan kontrak elektronik, seperti video conference.

RPP Perdagangan Elektronis akan mengatur tentang detail konfirmasi perjanjian jual beli yang harus dipenuhi oleh konsumen, sehingga konsumen tidak melakukan kesepakatan sebelum seluruh persyaratan terpenuhi. Pengaturan mekanisme acceptance berkaitan tentang pernyataan telah diterimanya suatu penawaran oleh konsumen. Pihak yang memberikan penawaran harus menjelaskan secara terperinci metode penerimaan jika penawaran tersebut diakseptasi (dalam bentuk konfirmasi), serta harus dipastikan bahwa perjanjian online yang disepakati sudah memilki pengamanan khusus seperti tanda tangan digital (digital signature).

RPP Perdagangan Elektronis juga mengatur tentang Penyelenggara perdagangan elektronis yang bekerjasama dengan penyedia jasa keuangan (PJK) untuk penyelesaian pembayaran transaksi wajib memastikan PJK memiliki tingkat kesehatan yang baik sesuai penilaian berkala oleh otoritas pengawas terkait.Penyelenggara perdagangan elektronis wajib melakukan due diligence untuk menilai tingkatkepatuhan PJK terhadap peraturan berlaku. Penyelenggara Ttransaksi perdagangan melalui transaksi elektronis (PTPMTE) wajib membuat perjanjian kerjasama yang memenuhi arm's length principle dengan PJK sebelum memulai kerjasama dalam penyelesaian transaksi pembayaran. ${ }^{12}$

PTPMSE adalah pelaku usaha penyedia sarana komunikasi elektornik yang digunakan untuk transaksi perdagangan. Untuk penyelenggara sarana perantara (intermediary services) adalah pelaku usaha penyedia sarana komunikasi elektronik yang hanya berfungsi sebagai perantara komunikasi elektronik antara pengirim dengan penerima. Untuk pedagang dan penyelenggara sarana perantara dapat berbentuk perorangan atau badan usaha. Sedangkan untuk PTPMSE wajib berbentuk badan usaha yang berbadan hukum Indonesia. Dalam RPP ini juga diatur mengenai pedagang, PTPMSE dan penyelenggara sarana perantara yang berkedudukan di luar negeri. ${ }^{13}$

Pasal 13 RPP menyebutkan bahwa pedagang, PTPMSE dan penyelenggara sarana perantara berkedudukan di luar negeri yang melakukan transaksi perdagangan melalui sistem elektronik dengan konsumen yang berkedudukan di Indonesia, dianggap melakukan kegiatan operasional di Indonesia.Untuk penjelasan pasal ini adalah kebijakan perdagangan melalui sistem elektronik pada dasarnya mengikuti kebijakan dalam negeri, sedangkan terhadap transaksi yang bersifat lintas batas negara mengikuti kebijakan perdagangan luar negeri dan atau perdagangan di

\footnotetext{
${ }^{12} \mathrm{ibid}$

${ }^{13}$ ibid
} 
wilayah perbatasan.

Dalam RPP juga diatur kewajiban pelaku usaha untuk memiliki tanda daftar khusus sebagai pelaku usaha transaksi perdagangan melalui sistem elektronik. Hal tersebut tertulis pada Pasal 18 RPP. PTPMSE dan pedagang yang memiliki sistem transaksi melalui elektronik wajib memiliki izin khusus perdagangan elektronik dari menteri. Izin ini juga berlaku bagi pedagang dan PTPMSE yang melakukan kegiatan usaha di dalam wilayah hukum Indonesia. Sedangkan penyelenggara sarana perantara tidak perlu izin dari menteri jika bukan merupakan pihak yang mendapatkan manfaat (beneficiary) atau tidak terlibat langsung dalam hubungan kontraktual para pihak yang melakukan transaksi perdagangan melalui sistem elektronik.Izin usaha sebagai penyelenggara jaringan dan jasa telekomunikasi merupakan domain kewenangan Kementerian Komunikasi dan Informatika. Sedangkan izin penyelenggaran sarana dan aplikasi perdagangan merupakan domain kewenangan Kementerian Perdagangan. ${ }^{14}$

\section{Ketentuan Perpajakan Dalam E-Commerce}

Hukum Pajak atau hukum fiskal di rumuskan sebagai berikut:

"Keseluruhan dari peraturan-peraturan yang meliputi wewenang pemerintah untuk mengambil kekayaan seseorang dan menyerahkannya kembali ke masyarakat dengan melalui kas negara, sehingga ia merupakan bagian dari hukum publik mengatur hubungan-hubungan hukum antar negara dan orang-orang atau badan-badan (hukum) yang berkewajiban membayar pajak". ${ }^{15}$

Pajak penghasilan ini adalah kewajiban bagi subjek pajak sebagaimana diatur dalam Pasal 2 ayat (1) UU RI No. 36 Tahun 2008 tentang Perubahan Keempat Atas UU No. 7 Tahun 1983 tentang Pajak Penghasilan (UU PPh).Disebutkan dalam pasal tersebut bahwa yang menjadi subjek pajak adalah: ${ }^{16}$

a. 1. orang pribadi

2. warisan yang belum terbagi sebagai satu kesatuan menggantikan yang berhak

\footnotetext{
${ }^{14} \mathrm{http} / / / \mathrm{www} \cdot h u k u m o n l i n e . c o m /$ berita/baca//mengintip-isi-rpp-iecommerce-i, diunduh pada tgl. 28 Juni 2015 jam 13.00.

${ }^{15}$ R. Santoso Brotodihardjo, "Pengantar Ilmu Hukum Pajak", Edisi ketiga, Bandung: PT. Refika Aditama, Bandung, 1998, hal.1.

${ }^{16}$ Undang-Undang RI Nomor 36 Tahun 2008 Tentang Perubahan Keempat Atas Undang-Undang Nomor 7 Tahun 1983 Tentang Pajak Penghasilan.
}

b. badan dan

c. bentuk usaha tetap.

Dalam Pasal 4 ayat (1) UU PPh ditegaskan bahwa penghasilan yang dikenakan pajak meliputi unsur: "tambahan kemampuan ekonomis yang diterima atau diperoleh wajib pajak baik yang berasal dari Indonesia maupun dari luar Indonesia yang dapat dipakai untuk konsumsi atau menambah kekayaan wajib pajak yang bersangkutan dengan nama atau bentuk apapun".

Dalam transaksi e-commerce perlu dibedakan mengenai wajib pajak dalam negeri dan wajib pajak luar negeri dan bentuk usaha tetap. Dalam Penjelasan Pasal 2 ayat (2) UU PPh: bahwa Subyek Pajak dibedakan antara subyek pajak dalam negeri dan subyek pajak luar negeri.subjek pajak dalam negeri menjadi wajib pajak apabila telah menerima atau memperoleh penghasilan yang besarnya melebihi penghasilan tidak kena pajak, sedangkan subjek pajak luar negeri sekaligus menjadi Wajib Pajak, sehubungan dengan penghasilan yang diterima dari sumber penghasilan di Indonesia atau diperoleh melalui bentuk usaha tetap di Indonesia. Dengan perkataan lain Wajib Pajak adalah orang pribadi atau badan yang telah memenuhi kewajiban subjektif dan objektif. Sehubungan dengan pemilikan NPWP, Wajib Pajak orang pribadi yang menerima penghasilan di bawah PTKP tidak perlu mendaftarkan diri untuk memperoleh NPWP. Bagi Wajib Pajak luar negeri yang menjalankan usaha atau melakukan kegiatan melalui bentuk usaha tetap di Indonesia, pemenuhan kewajiban perpajakannya dipersamakan dengan pemenuhan kewajiban perpajakan wajib pajak dalam negeri sebagaimana diatur dalam undang-undang ini dan undang-undang tentang Ketentuan Umum dan Tata Cara Perpajakan. ${ }^{17}$

Kewajiban untuk membayarkan pajak penghasilan ini timbul sejak saat orang pribadi atau badan tersebut menjalankan usaha atau melakukan kegiatan sehingga memperoleh penghasilan. ${ }^{18}$ Kementerian Perdagangan mengakui bahwa kesulitan untuk menyusun PP ecommerce ini adalah mengenai pengenaan pajaknya. Apakah, atas transaksi berbasis e-commerce ini nantinya akan dikenakan pajak atau tidak. Sementara itu, Ditjen Pajak (DJP) dengan tegas menyatakan bahwa

\footnotetext{
${ }^{17}$ Penjelasan Pasal 2 ayat (1) Undang-Undang RI Nomor 17 tahun 2000 tentang Perubahan Ketiga atas Undang-Undang Nomor 7 tahun 1983 tentang Pajak Penghasilan.

${ }^{18}$ Djamaluddin Gade dan Muhammad Gade, "Hukum Pajak", Jakarta: Lembaga Penerbit Fakultas Ekonomi Universitas Indonesia, 2002, hal. 79 .
} 
e-commerce adalah merupakan transaksi perdagangan barang dan/atau jasa lainnya, tetapi hanya berbeda dalam hal cara atau alat yang digunakan saja. Sehingga, perlakukan pajak e-commerce sama dengan perlakuan pajak atas perdagangan lainnya, termasuk tidak ada aturan khusus perpajakan yang mengatur transaksi ecommerce ini. ${ }^{19}$ Dengan kata lain bahwa penerapan ketentuan pajak jual beli untuk toko online pada dasarnya dipersamakan dengan toko tradisional.Untuk wajib pajak (dalam hal ini pengusaha online) yang tidak melaksanakan kewajiban membayar pajaknya, DJP akan melakukan penagihan pajak.

DJP telah memetakan empat model transaksi ecommerce, yaitu: Online Marketplace, Classified Ads, Daily Deals dan Online Retail.

1) Online Marketplace adalah kegiatan menyediakan tempat kegiatan usaha berupa toko internet seba- gai Online Marketplace Merchant untuk menjual barang atau jasa. Dalam model transaksi ini, ada imbalan, dalam bentuk rent fee atau registration fee atas jasa penyediaan tempat atau waktu memajang iklan barang dan/atau jasa dan melakukan penjualan di toko internet melalui mal internet. Selain itu, ada sejumlah uang yang dibayarkan oleh Onli- ne Marketplace Merchant ke penyelenggara Onli- ne Marketplace sebagai komisi atas jasa perantara pembayaran atas penjualan barang dan/atau jasa.

2) Classified Ads adalah kegiatan menyediakan tempat dan/atau waktu untuk memajang iklan barang dan/atau jasa yang dilakukan oleh pengiklan melalui situs yang disediakan oleh Penyelenggaran Classified Ads. Kemudian pengiklan membayar sejumlah uang sebagai transaction fee kepada penyelenggara Classified Ads yang merupakan objek PPh dan PPN.

3) Daily Deals mirip dengan Online Marketplace namun alat pembayaran yang digunakan berupa voucher.

4) Online Retail dimana kegiatan menjual barang dan/atau jasa yang dilakukan secara langsung oleh penyelenggara Online Retail kepadapembeli di situs Online Retail.

Dalam keempat model transaksi e-commerce ini, ada pembayaran imbalan atau penghasilan karena jualbeli barang/atau jasa yang merupakan objek pajak

\footnotetext{
${ }^{19}$ http://www.kemenkeu.go.id/en/node/41764, Menyasar Pajak Transaksi E-Commerce, diunduh pada tgl.28 Juni, jam. 12.00. ${ }^{20}$ Ibid.
}

Pajak Penghasilan (PPh) dan Pajak Pertambahan Nilai (PPN) yang akan dikenakan pajak menurut aturan perpajakan yang berlaku. ${ }^{20} \mathrm{Jika}$ toko online menjual barang atau jasa yang dikenakan Pajak Pertambahan Nilai (PPN), ia juga harus menerbitkan faktur pajak.

Dengan adanya Peraturan Dirjen Pajak No PER32/PJ/2010 Tahun 2010 tentang Pelaksanaan Pengenaan Pajak Penghasilan Pasal 25 bagi Wajib Pajak Orang Pribadi Pengusaha Tertentu ("Perdirjen Pajak No.32 tahun 2010"), pengusaha perorangan melalui media internet (online) wajib membayar pajak penghasilan sesuai aturan. Meskipun tidak memiliki tempat usaha secara fisik, kewajiban membayar PPh ini tetap mengikat bagi mereka.

Perhitungan pajak bagi pengusaha online sebagai Wajib Pajak Orang Pribadi Pengusaha Tertentu (WPOPPT) dikenakan angsuran atas pajak penghasilan sebesar 0,75\% dari jumlah peredaran bruto setiap bulan dari masing-masing tempat usaha, yang dilakukan melalui Bank Persepsi atau Bank Devisa Persepsi atau Kantor Pos Persepsi dengan menggunakan Surat Setoran Pajak yang mencantumkan Nomor Pokok Wajib Pajak (Pasal 3 ayat (1) dan (2) Perdirjen pajak 32/2010). ${ }^{21}$

Jika merujuk pada Pasal 26 ayat (1) UU PPh, maka PPh yang dikenakan/dipotong atas penghasilan yang bersumber dari Indonesia yang diterima atau diperoleh Wajib Pajak (WP) luar negeri selain bentuk usaha tetap (BUT) di Indonesia. Penghindaran Pajak Berganda (P3B) dimaksudkan untuk mengatur pembagian hak pemajakan dari masing-masing negara dnegan tujuan untuk mencegah timbulnya pajak ganda. Pembagian hak pemajakan dilakukan dengan membatasi hak pemajakan negara sumber.

Pada umumnya hak pemajakan negara sumber dapat diklassifikasikan menjadi 3, yaitu: (1) hak pemajakan penuh (exclusively taxing rights), (2) hak pemajakan terbatas (limited taxing rights), (3) pelepasan hak pemajakan (relinquished taxingright). Kedudukan P3B adalah lex specialis terhadap undangundang domestik yang berlaku di masing-masing negara pihak pada persetujuan. Apabila negara sumber sesuai dengan P3B diatur bahwa negara sumber tidak memiliki hak pemajakan atas suatu penghasilan yang timbul dari suatu wilayah yurisdiksinya, maka ketentuan domestic yang mengatur bagaimana pemajakan

\footnotetext{
${ }^{21}$ Peraturan Direktorat Jenderal Pajak Nomor PER-32/PJ/2010 Tahun 2010 tentang Pelaksanaan Pengenaan Pajak Penghasilan Pasal 25 bagi Wajib Pajak Orang Pribadi Pengusaha Tertentu.
} 
atas penghasilan tidak dapat diterapkan, demikian pula sebaliknya apabila P3B mengatur bahwa sumber memiliki hak untuk memajaki penghasilan itu, maka bagaimana cara memajakinya diatur sesuai dengan ketentuan undang-undang domestiknya. ${ }^{22}$

\section{URGENSI PENERAPAN PAJAK PADA TRANSAKSI E-COMMERCE}

Organization for Economic and Commerce Development The Technical Advisory Group on Treaty Characterisation of Electronic Commerce Payment (OECD TAG), merupakan suatu organisasi yang melakukan penelitian dan memberikan rekomendasi mengenai penentuan jenis penghasilan dari semua transaksi e-commerce. Pada 1 Februari 2001 OECD TAG menerbitkan The TAG Final Report yang membagi jenis-jenis transaksi e-commerce menjadi 28 jenis transaksi e-commerce. ${ }^{23}$

Dalam ketentuan tersebut dapat diketahui bahwa OECD lebih cenderung memihak pada hak negara domisili untuk memungut pajak. Sejak ketentuan OECD tersebut tidak banyak perjanjian yang dilakukan oleh negara-negara berkembang dan negara-negara anggota OECD (30 anggota penuh, 25 diantaranya adalah negara dengan pendapatan tinggi) yang umumnya merupakan negara-negara pengekspor modal. Jika terjadi perselisihan masalah penghindaran pajak berganda yang digunakan adalah ketentuan dalam OECD. Pemberlakuan ketentuan OECD menyebabkan banyaknya kerugian yang diderita oleh negara sumber, karena tidak seimbangnya antara penerimaan pajak yang diberikan oleh negara sumber dan penerimaan pajak yang diberikan oleh negara domisili. Padahal seperti diketahui bahwa sumber hukum perpajakan internasional Indonesia adalah perjanjian penghindaran pajak berganda $(\mathrm{P} 3 \mathrm{~B})$ atau tax treaty dalam Konvensi Wina tahun 1961 dan 1963.

Pada akhir tahun 2009, Indonesia menjadi peserta dalam Forum Global OECD tentang Transparansi dan Pertukaran Informasi untuk Keperluan Pajak. Forum tingkat tinggi ini memantau implementasi standar pajak yang telah disepakati secara internasional untuk pertukaran informasi yang efektif, dengan tujuan me-

\footnotetext{
${ }^{22}$ John Hutagol, "Seri Perpajakan Internasional, Pemahaman Praktis Perjanjian Penghindaran Pajak Berganda Indonesia Dengan Negara-negara di Kawasan Eropa“, Jakarta: Salemba Empat, 2000, hal.22.

23 http://www.oecd.org/tax/treaties/ecommercereportsandtechnicalpapers.htm, diunduh pada tgl.28 Juni 2015, pukul 15.00 .
}

merangi penghindaran pajak lintas batas negara di lebih dari 80 yurisdiksi negara-negaraOECD dan nonOECD. Forum ini melakukannya melalui penerbitan secara reguler publikasi hasil ulasan negara (country review). ${ }^{24}$

Transaksi e-commerce terkait dengan perpajakan internasional sama halnya dengan transaksi lintas batas (cross border transaction) lainnya, hak pemajakan suatu negara atas penghasilan dari transaksi internasional tersebut bergantung pada jenis penghasilannya. Terdapat kesepakatan para ahli perpajakan internasional berkenaan dengan hak pemajakan (taxing right) atas penghasilan-penghasilan dari transaksi-transaksi internasional (cross bordertransaction), diantaranya: hak memungut atas pajak penghasilan pada dasarnya harus diberikan kepada negara domisili, negara yang menerapkan ini menganut prinsip world wide inco$m e$, artinya subyek pajak yang berdomisili di negara tersebut dikenai pajak atas seluruh penghasilan yang bersumber dari negara manapun di dunia; negara lain selain negara domisili dapat memungut pajak apabila negara tersebut tempat sumber penghasilan; jenis penghasilan dari usaha, dimana negara sumber yang boleh memungut pajak adalah negara dimana dilakukannya kegiatan usaha melalui bentuk usaha tetap atau negara di luar negara domisili tempat pendirian kantor cabang, pabrik, bengkel atau tempat lain yang bersifat permanen. ${ }^{25}$

Seperti diketahui bahwa e-commerce merupakan jenis transaksi perdagangan yang tidak mengenal batas geografis antar negara, dimana transaksi dilakukan melalui media internet, dengan lokasi server atau komputer yang berbeda (tergantung dari keberadaan atau lokasi dari internet service provider ${ }^{26}$ ). Hal inilah yang menyulitkan untuk menentukan dimana tempat usaha tetap (fixed place of business) sebagai salah satu prasyarat adanya bentuk usaha tetap (BUT), seperti yang diisyaratkan ketentuan dalam OECD.

Jika suatu perusahaan mengunakan web server dan peralatan lainnya yang berada dalam sebuah bangunan fisik yang berada di negara yang sama dengan kedudukan perusahaan itu maka disebut bentuk usaha tetap fisik. Jika peralatan berada di negara lain,

\footnotetext{
${ }^{24}$ Ibid.

${ }^{25}$ John Hutagaol, op.cit. hal.22.

${ }^{26}$ Penyelenggara Jasa Internet (Internet Service Provider) adalah perusahaan atau badan yang menyediakan jasa sambungan Internet dan jasa lainnya yang berhubungan. Kebanyakan perusahaan telepon merupakan penyedia jasa Internet. Mereka menyediakan jasa seperti hubungan ke Internet, pendaftaran nama domain, dan hosting, Misalnya Bit.net, CBN.net, Firstasia.net, solusi.net, dll.
} 
maka dianggap sebagai investasi luar negeri. Keuntungan dari investasi akan dikenakan pajak di negara mana investasi tersebut ditanamkan. Apabila usaha ecommerce dari luar negeri memiliki web server di Indonesia, dimana server tersebut diletakan dalam bangunan di Indonesia maka perusahaan $e$-commerce dapat dianggap sebagai bentuk usaha tetap di Indonesia.

Bila mengacu pada ketentuan OECD bahwa penentuan bentuk usaha tetap (BUT) bagi perusahaan yang menjalankan bisnis e-commerce dan menempatkan server miliknya pada suatu bangunan pada suatu wilayah yang berada di suatu negara dalam jangka waktu tertentu inilah yang dianggap sebagai BUT. Maka kesulitan dalam menentukan dimana lokasi subyek pajak menjadi lebih jelas. Begitupun di dalam penentuan transaksi e-commerce yang melintasi batas negara, maka negara sumber dapat mengenakan pajak penghasilan atas perusahaan e-commerce dimana servernya berada di wilayah negara sumber akan menjadi lebih jelas.

Mengenai jenis-jenis penghasilan yang dari transaksi e-commerce berdasarkan ketentuan OECD TAG dimana terdapat 28 jenis transaksi e-commerce, yaitu:

(1) electronic order processing of tangible products,

(2) electronic ordering and downloading of digital product, (3) electronic ordering and downloading of digital product for purpose exploitation of the copyright, (4) updates and add-ons, (5) limited duration software and other digital information licences, (6) single use software or other digital product, (7) application hosting - separate licences, (8) application hosting - bundled contract, (9) application service provider (APS), (10) ASP licences fees, (11) website hosting, (12) software maintenance, (13) data warehousing, (14) customer support over a computer network, (15) data retrieval, (16) delivery of exclusive or other high value data, (17) advertising, (18) electronic access to professional advice, (19) technical information, (20) information delivery, (21) access to an interactive web site, (22) online shopping portals, (23) online auction, (24) sales referral programs, (25) content acquisition transactions, (26) streamed web based broadcasting, (27) carriage fees, (28) subscription to a web site allowing the downloading of digital products. ${ }^{27} \mathrm{a}$

Jenis penghasilan dari transaksi e-commerce yang paling banyak disebutkan dalam ketentuan
OECD TAG adalah mengenai penghasilan dariusaha e-commerce dan royalti. Jika dihubungan dengan ketentuan pada Pasal 4 ayat (1) UU RI Nomor 36 tahun 2008 Tentang Perubahan Keempat Atas UU Nomor 7 Tahun 1983 Tentang Pajak Penghasilan bahwa penghasilan yang dihasilkan dalam transaksi e-commerce ruang lingkupnya masih terbatas pada penghasilan usaha dan royalti. Penerapan pajak atas suatu usaha e-commerce baru dapat dikenakan apabilapengusaha e-commerce memiliki bentuk usaha tetap seperti dalam ketentuan PPh Pasal 23 sebesar $15 \%$ dari jumlah bruto pihak yang membayar royalti.

Transaksi e-commerce tahun 2013 mencapai US\$ 8 Milyar, tahun 2015 diprediksi nilainya mencapai US\$ 25 Milyar dari total penduduk sekitar 253 juta jiwa dengan pengguna internet di Indonesia sekitar 74 juta jiwa. Sekitar 7\% diantara pengguna internet berbelanja lewat online alias tumbuh $212,5 \%$ dari posisi 2 tahun lalu, jika sekitar 5,18 juta pengguna internet menghabiskan dana Rp.500.000,-/ bulan artinya penjualan online mencapai Rp.2,9 Trilyun/ bulan atau Rp.34,8 Trilyun / tahun. ${ }^{28}$

Melihat sangat besarnya potensi pendapatan negara dari sektor pajak penghasilan para wajib pajak dalam transaksi e-commerce itulah, maka urgensi peraturan pemerintah tentang perdagangan elektronik terhadap pengenaan pajak pada transaksi e-commerce harus segera diundangkan supaya terjadi kepastian hukum dalam transaksi e-commerce dan pemerintah sebagai pihak yang berwenang memungut pajak. Namun sebelum RPP perdagangan elektronik disahkan menjadi Peraturan Pemerintah, sebaiknya DJP perlu pengkajian lebih mendalam isi RPP dengan melibatkan para pelaku bisnis online, pengelola e-commerce, asosiasi e-commerce dan juga melibatkan para akademisi.

\section{KESIMPULAN:}

1. Ketentuan pajak penghasilan yang sudah ada dan kemudian diterapkan pada transaksi e-commerce belum mendukung transaksi e-commerce, karena perangkat yang ada belum mengatur secara lengkap mengenai ketentuan perpajakan atas transaksi e-commerce. Mengenai penentuan suatu transaksi e-commerce dianggap memiliki bentuk usaha tetap (BUT) dalam kaitannya dengan subyek

\footnotetext{
${ }^{27} \mathrm{http}$ ///www.oecd.org/tax/treaties/ecommercereportsandtechnicalpapers.html, diunduh pada tgl.28 Juni 2015, jam.15.10.
}

\footnotetext{
${ }^{28}$ Andrie Indardie, dkk, "Penting Regulasi Segera", Tabloid Kontan, edisi 29 Juni-5 Juli 2015, hal.3.
} 
pajak, UU RI Nomor 36 tahun 2008 dalam Pasal 5 ayat (1) huruf p mengenai bentuk usaha tetap, namun ketentuan ini masih belum lengkap karena belum menjelaskan secara spesifik mengenai jenis-jenis transaksi e-commerce seperti yang direkomendasikan dalam OECD TAG bahwa ada 28 jenis transaksi yang sebagian besar transaksi e-commerce menghasilkan pendapatan usaha dan royalti.

2. Melihat sangat besarnya potensi pendapatan negara dari sektor pajak penghasilan para wajib pajak dalam transaksi e-commerce itulah, maka urgensi peraturan pemerintah tentang perdagangan elektronik terhadap pengenaan pajak pada transaksi ecommerce harussegeradiundangkan supaya terjadi kepastian hukum dalam transaksi e-commerce dan pemerintah sebagai pihak yang berwenang memungut pajak. Namun sebelum RPP perdagangan elektronik disahkan menjadi Peraturan Pemerintah, sebaiknya DJP perlu pengkajian lebih mendalam isi RPP dengan melibatkan para pihak terkait dengan transaksi e-commerce.

\section{SARAN}

1. Ketentuan penerapan pajak dalam RPP Perdagangan Elektronik sebagai peraturan pelaksana dari Pasal 65 dan 66 UU Nomor 7 tahun 20014 tentang Perdagangan, haruslah dikaji ulang secara lebih mendalam dengan mengacu pada UU Nomor 11 tahun 2008 tentang Informasi dan Transaksi Elektronik sebagai payung hukum su- paya dapat memberikan kepastian hukum bagi para pelaku transaksi e-commerce dan juga pemerintah dalam kepentingan pemungutan pajak penghasilan, dalam penyusunan RPP Perdagangan Elektronik perlu juga dipertimbangkan rekomendasi dari OECD TAG mengenai ke-28 jenis transaksi e-commerce.

2. Perlunya sosialisasi ke masyarakat khususnya pelaku transaksi e-commerce dan pengelola ecommerce mengenai penerapan pajak penghasilan atas transaksi e-commerce yang dilakukan. Bahwa pada prinsipnya kewajiban warga negara yang baik adalah membayar pajak seperti para pengusaha bisnis secara tradisional (offline), mengenai pajak penghasilan dari usaha dalam transaksi e-commerce, perlu dipikirkan para perumus RPP Perdagangan Elektronik apakah perlu diperlakukan hal yang sama dengan pemungutan pajak royalti, dimana pengenaan pajak secara withholding tax, jadi pajak penghasilan pada transaksi e-commerce sudah dapat dipungut negara meskipun bentuk badan usaha tetap (BUT) belum ada. Hal ini untuk memaksimalkan pendapatan dari pajak penghasilan yang diperoleh Indonesia sebagai negara sumber, serta perlunya Direktorat Jendral Pajak (DJP) membentuk suatu tim pengawas terlebih dahulu yang bertugas mengawasi setiap transaksi e-commerce, khususnya setiap transaksi e-commerce yang berada di Indonesia, hal ini untuk memudahkan dalam menentukan dimana negara sumber berada. 


\section{Daftar Pustaka}

\section{Buku:}

Departement of Economic and Social Affairs, "International Standard Industrial Classification of All Economic Activities”. New York, 2008, Rev.IV.

Djamaluddin Gade dan Muhammad Gade, “Hukum Pajak”, Jakarta: Lembaga Penerbit Fakultas Ekonomi Universitas Indonesia, 2002.

John Hutagaol, "Seri Perpajakan Internasional, Pemahaman Praktis Perjanjian Penghindaran Pajak Berganda Indonesia Dengan Negara-negara di Kawasan Eropa”, Jakarta: Salemba Empat, 2000.

M. Suyanto, "Strategi Periklanan pada e-commerce Perusahaan Top Dunia", Yogyakarta: Andi, 2003. Onno W. Purbo dan Aang Arif Wahyudi, “Mengenal E-Commerce”, Jakarta: Elek Media Komputindo, 2001.

R. Santoso Brotodihardjo, "Pengantar Ilmu Hukum Pajak", Edisi ketiga, Bandung: PT. Refika Aditama, Bandung, 1998.

\section{Undang-Undang:}

- Kitab Undang-undang Hukum Perdata.

- Undang-Undang RI Nomor 17 tahub 2000 tentang Perubahan Ketiga atas Undang-Undang Nomor 7 tahun 1983 tentang Pajak Penghasilan.

- Undang-Undang RI Nomor 36 Tahun 2008 Tentang Perubahan Keempat Atas Undang-Undang Nomor 7 Tahun 1983 Tentang Pajak Penghasilan.

- Undang-Undang RI Nomor. 7 tahun 2014 tentang Perdagangan.

- Peraturan Direktorat Jenderal Pajak Nomor PER-32/PJ/2010 Tahun 2010 tentang Pelaksanaan Pengenaan Pajak Penghasilan Pasal 25 bagi Wajib Pajak Orang Pribadi Pengusaha Tertentu.

\section{Surat Kabar:}

Tabloid Kontan, Edisi 29 Juni-5 Juli 2015.

\section{Internet}

- http://inet.detik.com/read/2015/03/26/132012/2870293/398/pengguna-internet-indonesia-tembus881-juta, diunduh pada tgl. 28 Juni 2015.

- http://www.pajak.go.id/content/article/pajak-sebagai-ujung-tombak-pembangunan, diunduh pada tgl. 28 Juni 2015.

- http://id.scribd.com/doc/65509415/Naskah-Akademik-RPP-Perdagangan-Secara-Elektronik\#scribd, diun- duh pada tgl. 28 Juni 2015. 
- http://www.hukumonline.com/berita/baca/lt558f510c0c66d/mengintip-isi-rpp-ie-commerce-i, diunduh pada tgl. 28 Juni jam 13.00.

- http://www.kemenkeu.go.id/en/node/41764, diunduh pada tgl.28 Juni, jam. 12.00.

- http://www.oecd.org/tax/treaties/ecommercereportsandtechnicalpapers.htm, diunduh pada tgl.28 Juni 2015, jam.15.00. 